\title{
Evaluation of Different Fungi Toxicants against Yellow Rust Diseases on Bread Wheat (Triticum aestivum L.) in the Cold Arid Zone of Kargil, Ladakh (J\&K), India
}

\author{
Nassreen F. Kacho ${ }^{1}$, Nazir A. Bhat ${ }^{2}$, Nazir Hussain ${ }^{1}$ and Kunzang Lahmo ${ }^{3}$ \\ ${ }^{1}$ KrishiVigyan Kendra, Kargill- 194103 Sher-e-Kashmir University of Agricultural Sciences \\ and Technology of Kashmir, India \\ ${ }^{2}$ Department of Plant Pathology, Faculty of Agriculture, Wadura Spore Kashmir, India \\ ${ }^{3}$ Krishi Vigyan Kendra, Leh, India \\ *Corresponding author
}

\section{A B S T R A C T}

Keywords

Fungicide,

Hexaconazole,

Cereals crop,

Yellow rust disease,

Propoconizole

Article Info

Accepted:

26 October 2019

Available Online:

10 November 2019
A field experiment was conducted to determine the efficacy of different triazole fungicides against yellow rust of wheat caused by Puccina striiformis. The experiment field was divided in three part one part sprayed with propoconizole. Five fungicide (propiconazole 10EC, tebuconazole $25 \mathrm{EW}$, difenconazole $25 \mathrm{EC}$, hexaconazole 5EC andazoxystrobulin+ difenconazole were used in the experiment. All the fungicide treatment significantly reduced the disease intensity by $6.1 \%$ to $9.5 \%$ as compared to control $(35.5 \%)$. The minimum disease intensity $(6.1 \%)$ was recorded in treatment where propoconizole before disease appearance and ozoxystrobulin +difenaconazole after disease appearance was sprayed fallowed by propiconazole and tebuconazole with disease intensity of $7.8 \%$. Whereas 8.2 percent disease intensity was recorded in treatment where propoconizole was again sprayed after disease appearance followed by hexaconazole (9.3\%). Whereas, maximum disease intensity was recorded where propoconzole and hexaconazole was sprayed.

\section{Introduction}

Bread wheat (Triticum aestivum L.) is one of the most widely grown and most consumed food crops all over the world. It is the second most important cereals crop after rice and it contributing substantially to the national food security by providing more than $50 \%$ of calories to the people. Wheat (Triticum aestivum L.) is a staple food of billions of people in the world, used to make flour for leavened, flat and steamed bread, cookies, 
cakes, pasta, noodles, beer and alcohol (Habib and Khan, 2003). Annually, wheat is produced on 224.53 million hectares of land and 672.2 million metric tons of wheat is produced in the world (FAO, 2013). According to this report the world average wheat production is 2.99 tons /ha.

In Kargil District of Ladakh (J\&K), wheat is the second most important crop after barley. However, the production and productivity of wheat is curtailed by various biotic and abiotic factors. Among the biotic factors, yellow rust disease is the most threaten and wheat production bottlenecks. Many part of District, particularly the cooler area, is now becoming hot spot for wheat rusts, where the periodic epidemics cause significant yield losses and reduction. Therefore, the present study was undertaken to check the best fungicide for controlling of yellow rust under cold arid zone of Kargil, Ladakh.

\section{Materials and Methods}

Bread wheat cultivar Krokar (Local), highly susceptible to yellow rust (Puccinia striiformis f.sp. tritici $\mathrm{W}$ ) disease was planted at yellow rust hot spot location; Stikchey (District Kargil) in plots of $2800 \mathrm{~m}^{2}$, during the year 2017 and 2018 and the experiment was laid in randomized block design (RBD) with three replications for each treatment. Seed rate of $240 \mathrm{~kg} / \mathrm{ha}$ was sown in $2^{\text {nd }}$ week of April. Test fungicides, Propiconazole 25 EC $(0.1 \%)$, Tebuconazole 10 EC (0.1\%), Difenconazole $(0.05 \%)$, Azoxystrobulin + Difenconazole $(0.05 \%)$, Hexaconazole 10EC $(0.05 \%)$, Mancozeb+carbendazim (0.25\%), Chlorothalonil $(0.3 \%)$ and Mancozeb $(0.3 \%)$, were used. The plot was first divided equally $\left(700 \mathrm{~m}^{2}\right)$ into four parts and sprayed one part with sterile water and another three with Propocanzole, Chlorothanil and Mancozeb before the appearance of yellow rust respectively. Second fungicide were applied at $5 \%$ severity level of yellow rust (booting crop growth stage) and remaining $300 \mathrm{~m}^{2}$ was kept as check. Test and check fungicides were applied manually using Knapsack sprayer delivering 250 liter of water/ha. Rust severity was recorded in percentage using modified Cobb Scale (Peterson et al., 1948).

\section{Results and Discussion}

In 2015-16 main cropping season yellow rust disease pressure was very high and excellent disease epidemics was developed to the level of creating significant difference among all experiment plots. Fungicide spray treatments significantly reduced the disease over control.

There was statistically significant difference between the test fungicides. In treatment $T_{11}$ (where Propiconazole @ $0.1 \%$ and Difenconazole @ $0.05 \%$ were sprayed) significantly reduced the disease intensity and incidence by $6.14 \%$ and $19.03 \%$ respectively fallowed by treatment $\mathrm{T}_{12}$ and $\mathrm{T}_{9}$ by 7.59 and 8.77 respectively. The treatment $T_{10}$ and $T_{13}$, was not significantly difference. However, from visual field observation all the test fungicides showed comparable level of efficacy in controlling disease as compared to unsprayed plot. It is witnessed from the Table 1 that treatment $\mathrm{T}_{2}, \mathrm{~T}_{4}, \mathrm{~T}_{7}, \mathrm{~T}_{14}$ and $\mathrm{T}_{21}$ are at par with each other. Similarly there is no statistical difference among $\mathrm{T}_{3}, \mathrm{~T}_{5}$ and $\mathrm{T}_{24}$. $\mathrm{T}_{18}$ and $\mathrm{T}_{23}$ are also at par with each other. It is evident from Table 2 that $\mathrm{T}_{17}, \mathrm{~T}_{20}, \mathrm{~T}_{26}$ and $\mathrm{T}_{27}$ showed comparable level of efficacy in reduction of rust severity and incidence. Whereas, $\mathrm{T}_{8}, \mathrm{~T}_{15}, \mathrm{~T}_{22}$ and $\mathrm{T}_{28}$ showed disease intensity ranged from $29.17 \%$ to $33.16 \%$ compared to the plot where only sterile water sprayed and control where disease intensity showed 39.17 and 41.09 respectively. 
Table.1 Detail of the fungi toxicants evaluated under field conditions

\begin{tabular}{|c|c|c|c|}
\hline Treatment No. & \multicolumn{3}{|c|}{$\begin{array}{l}\text { Treatment Code Treatment Details } \\
\text { First Spray(BD)Second Spray(AD) }\end{array}$} \\
\hline $\mathrm{T}-1$ & $\mathrm{P}_{0} \mathrm{~F}_{0}$ & \multirow{7}{*}{ Sterile water } & Sterile water \\
\hline $\mathrm{T}-2$ & $\mathrm{P}_{0} \mathrm{~F} 1$ & & Propiconazole@0.1\% \\
\hline $\mathrm{T}-3$ & $\mathrm{P}_{0} \mathrm{~F} 2$ & & Tebuconazole@0.1\% \\
\hline $\mathrm{T}-4$ & $\mathrm{P}_{0} \mathrm{~F} 3$ & & Difenconazole@0.05\% \\
\hline $\mathrm{T}-5$ & $\mathrm{P}_{0} \mathrm{~F} 4$ & & $\begin{array}{c}\text { Azoxystrobulin+ Difenconazole @ } \\
0.05 \%\end{array}$ \\
\hline T-6 & $\mathrm{P}_{0} \mathrm{~F} 5$ & & Hexaconazole @ 0.05\% \\
\hline $\mathrm{T}-7$ & $\mathrm{P}_{0} \mathrm{~F} 6$ & & Mancozeb+carbendazim @0.25\% \\
\hline $\mathrm{T}-8$ & $\mathrm{P}_{1} \mathrm{~F}_{0}$ & \multirow{7}{*}{ Propiconazole@0.1\% } & Sterile water \\
\hline T-9 & $\mathrm{P}_{1} \mathrm{~F} 1$ & & Propiconazole@0.1\% \\
\hline $\mathrm{T}-10$ & $\mathrm{P}_{1} \mathrm{~F} 2$ & & Tebuconazole@0.1\% \\
\hline $\mathrm{T}-11$ & $\mathrm{P}_{1} \mathrm{~F} 3$ & & Difenconazole@ 0.05\% \\
\hline $\mathrm{T}-12$ & $\mathrm{P}_{1} \mathrm{~F} 4$ & & $\begin{array}{c}\text { Azoxystrobulin+ Difenconazole @ } \\
0.05 \%\end{array}$ \\
\hline $\mathrm{T}-13$ & $\mathrm{P}_{1} \mathrm{~F} 5$ & & Hexaconazole @ 0.05\% \\
\hline $\mathrm{T}-14$ & $\mathrm{P}_{1} \mathrm{~F} 6$ & & Mancozeb+carbendazim @0.25\% \\
\hline $\mathrm{T}-15$ & $\mathrm{P}_{2} \mathrm{~F}_{0}$ & \multirow{7}{*}{ Chlorothalonil@0.3\% } & Sterile water \\
\hline $\mathrm{T}-16$ & $\mathrm{P}_{2} \mathrm{~F} 1$ & & Propiconazole@0.1\% \\
\hline $\mathrm{T}-17$ & $\mathrm{P}_{2} \mathrm{~F} 2$ & & Tebuconazole@0.1\% \\
\hline $\mathrm{T}-18$ & $\mathrm{P}_{2} \mathrm{~F} 3$ & & Difenconazole@0.05\% \\
\hline $\mathrm{T}-19$ & $\mathrm{P}_{2} \mathrm{~F} 4$ & & $\begin{array}{c}\text { Azoxystrobulin+ Difenconazole @ } \\
0.05 \%\end{array}$ \\
\hline $\mathrm{T}-20$ & $\mathrm{P}_{2} \mathrm{~F} 5$ & & Hexaconazole@ $0.05 \%$ \\
\hline $\mathrm{T}-21$ & $\mathrm{P}_{2} \mathrm{~F} 6$ & & Mancozeb+carbendazim @0.25\% \\
\hline T-22 & $\mathrm{P}_{3} \mathrm{~F}_{0}$ & \multirow{7}{*}{ Mancozeb@ 0.3\% } & Sterile water \\
\hline $\mathrm{T}-23$ & $\mathrm{P}_{3} \mathrm{~F} 1$ & & Propiconazole@0.1\% \\
\hline $\mathrm{T}-24$ & $\mathrm{P}_{3} \mathrm{~F} 2$ & & Tebuconazole@0.1\% \\
\hline $\mathrm{T}-25$ & $\mathrm{P}_{3} \mathrm{~F} 3$ & & Difenconazole@ 0.05\% \\
\hline $\mathrm{T}-26$ & $\mathrm{P}_{3} \mathrm{~F} 4$ & & $\begin{array}{c}\text { Azoxystrobulin+ Difenconazole @ } \\
0.05 \%\end{array}$ \\
\hline $\mathrm{T}-27$ & $\mathrm{P}_{3} \mathrm{~F} 5$ & & Hexaconazole @ 0.05\% \\
\hline $\mathrm{T}-28$ & $\mathrm{P}_{3} \mathrm{~F} 6$ & & \\
\hline $\mathrm{T}-29$ & Check & - & - \\
\hline
\end{tabular}

BF- Before Disease, AD- After Disease 
Table.2 Evaluation of different $t$ fungicide efficacy against yellow rust disease of wheat

\begin{tabular}{|c|c|c|}
\hline Treatment & Disease Intensity (\%) & $\begin{array}{c}\text { Disease Incidence } \\
(\%)\end{array}$ \\
\hline $\mathbf{T}_{1}$ & 39.17 & 72.87 \\
\hline $\mathbf{T}_{2}$ & 20.60 & 37.60 \\
\hline $\mathbf{T}_{3}$ & 17.12 & 35.13 \\
\hline $\mathbf{T}_{4}$ & 21.47 & 35.22 \\
\hline $\mathbf{T}_{5}$ & 17.46 & 32.51 \\
\hline$T_{6}$ & 19.60 & 36.20 \\
\hline $\mathbf{T}_{7}$ & 20.40 & 69.13 \\
\hline$T_{8}$ & 32.36 & 57.73 \\
\hline $\mathbf{T}_{9}$ & 8.77 & 21.27 \\
\hline$T_{10}$ & 9.20 & 17.19 \\
\hline$T_{11}$ & 6.14 & 19.03 \\
\hline$T_{12}$ & 7.59 & 15.36 \\
\hline$T_{13}$ & 9.83 & 20.40 \\
\hline$T_{14}$ & 22.48 & 39.40 \\
\hline$T_{15}$ & 31.93 & 71.79 \\
\hline$T_{16}$ & 15.33 & 35.11 \\
\hline$T_{17}$ & 13.59 & 33.18 \\
\hline$T_{18}$ & 15.07 & 33.07 \\
\hline$T_{19}$ & 11.03 & 31.03 \\
\hline $\mathbf{T}_{20}$ & 13.64 & 32.23 \\
\hline $\mathbf{T}_{21}$ & 21.77 & 53.75 \\
\hline $\mathbf{T}_{22}$ & 33.16 & 73.06 \\
\hline$T_{23}$ & 15.09 & 35.33 \\
\hline $\mathbf{T}_{24}$ & 17.49 & 35.11 \\
\hline$T_{25}$ & 14.20 & 33.32 \\
\hline$T_{26}$ & 10.62 & 33.01 \\
\hline $\mathbf{T}_{27}$ & 13.10 & 34.45 \\
\hline$T_{28}$ & 29.17 & 52.87 \\
\hline $\mathbf{T}_{29}($ Check $)$ & 41.09 & 75.29 \\
\hline $\mathrm{CD}(\mathrm{p}=0.05)$ & 2.64 & 2.54 \\
\hline
\end{tabular}

Different studies from different part of the world reported yield increase in wheat due to fungicide application and growing yellow rust resistant variety. Hussain et al., (2018) noted the yield of wheat in Kargil district increased by $7.73 \mathrm{q} / \mathrm{ha}$ in yellow rust resistant variety HD267. In 2009 Wegulo et al., reported that up to $42 \%$ of yield loss by yellow rust was prevented by applying foliar fungicide to wheat. Kelly (2001) and Alemu and Mideksa (2016) also reported that propiconazole significantly increased winter wheat yield by 77\%. Ransom and McMullen (2008) showed that tebuconazole and propaconazole improved yield by 5.5 to $44.0 \%$. 


\section{References}

Alemu, W. and Mideksa,T.2016.Verification and Evaluation of Fungicides Efficacy against Wheat Rust Diseases on Bread Wheat (Triticum aestivum L.) in the Highlands of Bale, Southeastern Ethiopia. International Journal of Research Studies in Agricultural Sciences I2(9): 35-40

FAO (2013). FAO Agricultural Production Statistics, http: faostat3.fao.org/as accessed on 17 April 2015

Kelley, K. W. 2001. Planting date and foliar fungicide effects on yield components and grain traits of winter wheat. Agronomy Journal 93(2): 380-389,

Khan A.S., Habib, I. 2003. Genetic Model of some economics traits in bread wheat (Triticum aestivumL.) Asian Journal of Plant Science 2 (17-24): 1153-1155

Nazir H., M. Mehdi, N. Fatima, M. Hussain,
E.Dar, Zarger K. and Asmat, S. 2018. Impact frontline demonstration on varietal evaluation of wheat (Triticum aestivum $\mathrm{L}$.) under cold arid condition of Kargil (J\&K). Indian Journal of Hill Farming. Special issue, 54-57

Peterson, R. F., Campbell, A. B. and Hannah, A. E. 1948. A diagrammatic scale for estimating rust intensity of leaves and stem of cereals. Canadian J. Res. Sect. 26: 496-500.

Ransom, J. K. and McMullen, M. P. 2008. Yield and disease control on hard winter wheat cultivars with foliar fungicides. Agronomy Journal 100 (4): 1130-1137

Wegulo, S. N., Breathnach, J. A. and Baenziger, P. S. 2009. Effect of growth stage on the relationship between tan spot and spot blotch severity and yield in winter wheat. Crop Protection 28(8): 696-702,

\section{How to cite this article:}

Nassreen F. Kacho, Nazir A. Bhat, Nazir Hussain, and Kunzang Lahmo. 2019. Evaluation of Different Fungi Toxicants against Yellow Rust Diseases on Bread Wheat (Triticum aestivum L.) in the Cold Arid Zone of Kargil, Ladakh (J\&K), India. Int.J.Curr.Microbiol.App.Sci. 8(11): 2390-2394. doi: https://doi.org/10.20546/ijcmas.2019.811.277 